\title{
Süt Sığırcılığı İşletmelerinde Robotlu Sağım Sistemi
}

\author{
Deniz ALIÇ
}

S.Metin YENER ${ }^{1}$

Geliş Tarihi: 12.09.2006

\begin{abstract}
Öz: Bu çalışmada, geleneksel sağım sistemleri ile başta Avrupa olmak üzere birçok ülkenin süt sığırcılığı işletmelerinde yaygın olarak kullanılan robotlu sağım sistemi hakkında bilgi verilmiştir. Otomatik sağımın ilk kullanımından başlayarak süt sığırcılığı işletmelerinde geçiş sürecine değinilmiştir. Bunun yanında robotlu sağım sisteminin ekipmanları, çalışma prensipleri ile robotlu sağımın ekonomi ve işgücü kullanımı, süt üretimi, süt kalitesi ve hayvan sağlığı bakımından önemi üzerinde durulmuştur.
\end{abstract}

Anahtar Kelimeler: Robotlu sağım sistemi, süt üretimi, süt kalitesi, robotlu sağım sisteminin ekipmanları.

\section{Robotic Milking System in Dairy Farms}

\begin{abstract}
In this research, robotic milking that was common used in dairy farms with the inclusion of mainly Europe was given information. Process of transition of system through dairy farms was mentioned as from automatic milking. Furthermore, work principles and equipments of robotic milking system, consequence in economy and labour, milk production, milk quality and animal health of robotic milking were emphasized.
\end{abstract}

Key Words: Robotic milking system, milk production, milk quality, equipment of robotic milking system.

\section{Giriş}

Sağım, bir süt sığırcılığı işletmesinin ana gelir kaynaklarından biri olan sütün elde edilmesi işlemidir. İnek doğumun ardından kuruya çıkarılıncaya kadar, miktarı değişmekle birlikte, sürekli süt üretmektedir (Akman 2003).

İnsanların beslenmesi ile kısa süreli süt üretiminin önemi, birçok ülkede süt endüstrisinin gelişmesini sağlayıcı olmuştur. Aslında evrensel süt üretiminin sadece \%2'sini serbest uluslararası ticaret ve \%3'ünü de kota anlaşması altındaki ticaret oluşturmaktadır (Creamer ve ark. 2002).

Süt sığırcılığında sağım, işletme içerisinde yapılan işlerin büyük bir kısmını oluşturmaktadır. Mekanizasyon olanağı olmayan ve işgücünden yoğun olarak yararlanılan işletmelerde sağım için harcanan zaman daha fazla olmaktadır. Bu nedenle sağım, süt sığırcılığı işletmelerinde önemle üzerinde durulması gereken günlük işlerden biridir.

Günümüz ekonomik koşulları her alanda olduğu gibi süt sığırcılığında da rekabeti beraberinde getirmiştir. Süt sığırcılığında ana ürün süt olduğu için ucuz ve kaliteli üretim ön plana çıkmıştır. Bu rekabet şartları süt sığırcılığının şekil değiştirmesine neden olmuştur. Süt sığırcılığı 3-5 baş ineğe sahip aile işletmeciliğinden 100, 200, 300 hatta 1000 başlık modern işletmelerde profesyonel yaklaşımlarla yapılmaya başlanmıştır. Bu şekilde yem ve işçilik giderleri işletmelerde işçiliği en aza indirgenmiş merkezi sistemler olarak geliştirilmiştir (Anonim 2002).

$\mathrm{Bu}$ makalede, geleneksel sağım sistemleri ile başta Avrupa olmak üzere birçok ülkede süt sığırcılığı işletmelerinde yaygın şekilde kullanılan robotlu sağım sistemi hakkında bilgi verilmiştir.

Sağım sistemleri: Elle sağım iki parmak arasında, başparmağı bükerek ve avuç içinde sağım olmak üzere üç farklı şekilde yapılmaktadır (Akman 2003). Makineli sağım ise modern süt sığırcılığı işletmelerinde ekonomik yönden önemli bir yere sahiptir. Özellikle hayvan sayısının fazla olduğu işletmelerde makineyle sağım bir zorunluluktur. Çünkü sağım makinesi işçiliğin ucuz olduğu bölgelerde de diğer bölgelerde olduğu gibi daha kaliteli süt elde edilmesine, işgücünün daha ekonomik kullanılmasına, otomasyona ve birim zamanda daha fazla inek sağılmasına imkan vermektedir (Philpot ve Nickerson 1991, Akman 2003).

Sağım makinesi, süt sağımında kullanılan ve genellikle sağım başlıkları, pulsatör, sütü toplayan ve dağıtan düzenekler, vakum sistemi, süt tankı ve regülatör ile bir veya daha çok sağım düzeni ile gerekli diğer parçalardan oluşan bir makinedir (Anonim 1986). Temelde meme başına aralıklı vakum uygulayan bir

\footnotetext{
${ }^{1}$ Ankara Üniv. Ziraat Fak. Zootekni Bölümü-Ankara
} 
araçtır. Vakum sayesinde süt memeden çıkarılarak bir güğüm ya da tankta toplanmaktadır (Akman 2003).

Farklı koşullar dikkate alınarak değişik tipte sağım makineleri geliştirilmiştir. Bunlar güğümlü sağım makineleri, boru hatı sağım sistemleri, sabit sağım sistemleri (ardışık, balık kılçığı, paralel ve döner) olarak üç genel grupta incelenebilir (Akman 2003).

Robotlu Sağım Sistemleri : Otomatik sağım makinesinin geliştirilmesi 1950 'li yıllara rastlamaktadır (Akman 2003). Çeşitli ülkelerde artan işgücü masrafları, sağım işleminde otomasyona geçilmesinin başlıca sebeplerinden biri olmuştur. Bu alandaki ilk uygulamalar otomatik yemleme üniteleridir. 80'lerin başlarında geleneksel sağım sisteminde otomasyon, sağlık problemlerinin belirlenmesi, süt veriminin kaydedilmesi sağım ekipmanlarının gelişmesi şeklinde olmuştur. Çoğu geleneksel sağım sistemlerinde, sağım yapan kişinin görevi memeyi sağıma hazırlamak, sağım başlıklarını takmak, sağım süresince süt akışını ve ineği kontrol etmekle sınırlanmıştır. Anılan gelişmeler ile yeni teknolojiler sağım sırasındaki işgücünün azaltılmasına ve çalışan personel başına daha fazla serbest zaman kalmasına neden olmuştur. Otomasyondaki son gelişmelerden biri de otomatik sağım başlıklarıdır. Bu yöndeki düşünce tamamen bir otomatik sağım sisteminden geliştirilmiştir. Otomatik sağım başlıklarına ilişkin sitemin gelişimi aşama aşama olmuştur. 18. yüzyılın sonunda ve 19. yüzyılın başında sağım başlıklarının takılması ile ilgili bütün Avrupa'da bir seri çalışma yapılmıştır (De Koning ve ark. 2001).

Ticari işletmelerdeki ilk otomatik sağım sistemi Kuzeybatı Avrupa'da uygulanmıştır. Otomatik sağım sistemlerindeki gelişmelerin anılan ülkelerde başlamasının nedenleri, aile tipi işletmelere ve işgücünün pahalı olmasına bağlanmaktadır. Süt fiyatlarının düşme eğilimi işgücü, arazi, bina ve mekanizasyon masraflarının artması işletmecileri zorlayıcı olmuştur (De Koning ve ark. 2001, Meijering 2004).

El ve makine ile sağım sistemlerinin bir kombinasyonu olarak, geleneksel sağım sistemlerinde sorumluluk gerektiren sağım yönteminin bütün fonksiyonlarını otomatikleştiren sistem, robotlu sağım sistemi ya da gönüllü sağım sistemi olarak ifade edilmektedir (Anonymous 2004).

Otomatik sağım sistemlerinin daha gelişmiş bir modeli olan robotlu sağım sistemi, 1992 yılında ilk defa Hollanda'da ticari süt sığırcılığı işletmelerinde kullanılmaya başlanmıştır. Aynı dönemde Almanya, Danimarka ve Fransa gibi diğer ülkeler robotlu sağım sistemini benimsedikten sonra sistem hızlı bir şekilde gelişim göstermiştir (De Koning ve ark. 2001, Wirtz ve ark. 2001, Van der Vorst ve De Koning 2002, Meijering 2004).

Robotlu sağım sistemi kullanan süt sığırcılığı işletmelerinin \%90'ından fazlası Kuzeybatı Avrupa'da bulunmaktadır. Bununla birlikte Kanada ile Amerika'da bu sistemin kullanım düzeyi oldukça iyidir (Reinemann ve Jackson 2000, Rodenburg ve Kelton 2001).

Büyük sürülere sahip işletmelerde, geleneksel sağım sistemlerinin kullanılması çok etkili olmamaktadır. Bu sistemlerde, hızlı ve verimli olmayan donanımların bulunması yanında az bir maliyet gerektirmelerine rağmen sağım çok fazla zaman almaktadır (Steevens 1992). Robotlu sağım sistemi teknolojisi ise, fazla iş gücü olmaksızın birim zamanda daha fazla ineğin sağılabilmesine olanak tanımaktadır.

Robotlu sağım, hem bir işletmenin sahip olduğu ineklerin süt verimi ve kalitesini arttırmakta hem de işletme sahibinin yaşam kalitesini iyileştirmektedir (Helgren ve Reinemann 2003).

Robotlu sağım ile geleneksel sağım sistemi arasındaki başlıca fark, her bir ineğin işletme sahibi bulunmadan sağılabilmesidir (Van't Land ve ark. 2000, Helgren ve Reinemann 2003). Robotlu sağımın işletme içerisindeki başlıca yararları, sağım sıklığının fazla olmasından dolayı süt veriminin artması, iş gücünün azalması, sağım zamanlarını düzenlemede çalışan bir personelin bulunmasına ihtiyaç duyulmaması şeklinde sayılabilmektedir (Van't Land ve ark. 2000, Anonymous 2004).

İnsan gözlemleri ve bunların sonucunda alınan kararlar, süt kalitesi ve meme sağlığını tespit etmede yeterli olmamaktadır. (Helgren ve Reinemann 2003, Anonymous 2004). Bu sebeple, robotlu sağım sisteminde sağım zamanlarında meme sağlığı ile inek üzerine yapılan görsel kontrolün yerini otomatik kontrol almaktadır. Bu şekilde anormal sütler tespit edilebildiği gibi, meme başları ile memenin temizlenmesi de usulüne uygun olarak yapılabilmektedir (Anonymous 2004).

Sağım robotları, bir işletme için tasarlandığı zaman, işgücünden tasarruf, verim, inek davranışı, ineklerin beslenme alışkanlığı ile yönetim pratiklerine etkisi irdelenmelidir (Van't Land ve ark. 2000).

Robotlu sağım sisteminin ekipmanları ve çalışma prensipleri: Robotlu sağımda, inekler insan denetimi olmaksızın herhangi bir zamanda sağım sistemine girmekte ve ahır içinde serbest hareket etmektedir. Memenin sağıma hazırlanması, sağım ünitelerinin takılması ve çıkarılması, inekleri tanıyan otomatik aygıtların kontrolü, sisteme ilişkin bilgisayar 
yardımıyla yapılmaktadır. Buradaki sistemler ek iş gücü olmaksızın birçok süt ineğinin bir aile işletmesinde sağılması amacıyla Avrupa'da geliştirilmiştir. Robotlu sağım sisteminin içerdiği aşamalar sırasıyla; elektrikle çalışan otomatik kapıların kapanması, ineğin tanınması, memenin hazırlanması, süt kalitesinin belirlenmesi, sağım başlıklarının takılması, sağımın denetlenmesi, sağım başlıklarının çıkarılması, sağım sonrası memenin bakımı, ineğin serbest bırakılması ve ahır ya da meraya dönüş, süt toplama tankı ile soğutucuya sütün transferi şeklinde sıralanabilir. (De Koning ve ark. 2001, Graves 2002, Reinemann 2002).

Robotlu sağım sistemi ekipmanlarının arasında bilgisayar, algılayıcılar, sağım durağı, otomatik kapılar, yemleme yeri, temizleme sistemi, sağım sistemi, süt ölçerler, soğutma tankı ve robotlu kol sayılabilir. Bunlarla ilgili ayrıntılı bilgiler sırasıyla aşağıda verilmiştir:

a) Bilgisayar: Sistemin bir parçası olan bilgisayar robotlu sağım sisteminin değişik fonksiyonlarını yönetmekte ve alışılmamış durumları ikaz etmektedir. Bilgisayar, farklı algılayıcılar tarafından toplanan verileri değerlendirmekte ve bu aşamada kendisine yüklenen bilgileri kullanmaktadır. Süt akışı ve miktarı her bir ineğin 4 meme başı için denetlenmekte ve daha önceki dönemlerdeki kayıtlı bilgiler ile karşılaştırılmaktadır. Farklar kaydedilmekte ve böylece hasta olan ineklerin erken dönemde saptanması mümkün olmaktadır (Anonymous 2005a).

Bilgisayar, sağım başlıklarının ineğe takılması, çıkarılması, inek memesinin sağıma hazırlanması aşamasında manevra yapabilen metal robot kolun hareketini de idare etmektedir.(Graves 2002). Bunun yanında, sağım zamanında ineğin tanınması, ineğe verilecek olan yemin belirlenmesi, sisteme giriş-çıkış kapılarının açılıp kapanmasından da sorumludur (Dick 2002, Radfor 2003).

b) Algılayıcılar: Sistemde bütün inekler girişte elektronik numaralar ile tanınmaktadır. Buradaki numaralar ineğin durumunu belirlemek için sağım durağı ile sistemin giriş kapısına yerleştirilen almaçlar sayesinde okunmaktadır (Oostra 2000).

Meme şekli ve meme başı pozisyonu, inekten ineğe değişmektedir. İnekler her ne kadar sabit dursalar da, sağım duraklarında hareket ettiklerinde meme başlarının pozisyonunda değişim olabilmektedir. Robotlu sağım sisteminde, meme ve meme başı pozisyonu, ölçülebilmekte ve bir veri setinde saklanabilmektedir. Sağım başlıkları ancak bu bilgilerin kullanımı ile başarılı bir şekilde takılabilmektedir. Bundan dolayı robotlu sisteminde meme başı yerlerinin belirlenmesine ihtiyaç duyulmaktadır. Meme ve meme başı konumlarının tespiti de algılayıcılar sayesinde olmaktadır. Bu iş için daha çok lazer, ultrasonik ya da görüş gücü olan kamera sistemi kullanılmaktadır. Bu cihazlar sayesinde ineğin meme ve meme başının konumu belirlenmekte, bilgisayar bu cihazlardan aldığı bilgiler dahilinde ineğin meme başlarına sağım başlıklarının takılması için diğer ekipmanlara komut vermektedir (De Koning ve ark. 2001, Graves 2002). Ancak, sistemin uygulandığı bölgenin nemli, kirli ve gübre ile bulaşık olmasından dolayı meme başlarının belirlenmesi olumsuz etkilenebilmektedir. Bundan dolayı, buradaki koşullara özellikle dikkat edilmesi gerekmektedir, aksi takdirde sistemin performansı düşmektedir (De Koning ve ark. 2001).

Süt akışının belirlenmesinde de algılayıcıların görevi bulunmaktadır. Süt akış algılayıcıları her bir meme başından süt iletim hattı içinde sütün akışını ölçmektedir. Buradaki algılayıcılar sağım başlıklarının otomatik olarak çıkarılmasında da benzer fonksiyonu göstermektedir. Sağım başlıkları manevra yapan robotlu kol ile takıldıktan sonra eğer süt akışı sabit bir zamanda meydana gelmezse sağım başlıkları robotlu kol tarafından direkt olarak çıkarılmaktadır. İnek sağımı tamamlanmışsa ve süt akışı azalmışsa, bilgisayar sağım vakumunu kesmekte ve sağım başlıklarını uzaklaştırmaktadır (Graves 2002). Şekil 1'de algılayıcılar yardımıyla meme başlarının seçimi görülmektedir.

Algılayıcılar süt kalitesinin belirlenmesinde de kullanılmaktadır. Illetkenlik, renk ve sıcaklık başlıca ölçülen üç özelliktir. Sağımın başlangıcında ya da süt toplama tankına sağılan süt gönderildikten sonra gerekli saptamaların yapılması için bilgisayar elde edilen bilgileri süt kalitesini ve meme sağlığını belirlemede kullanmaktadır. Burada mastitis ve diğer sağlık problemlerinin tespit edilmesi durumunda işletmecinin elde edilen bilgileri kayıt etmesi ve

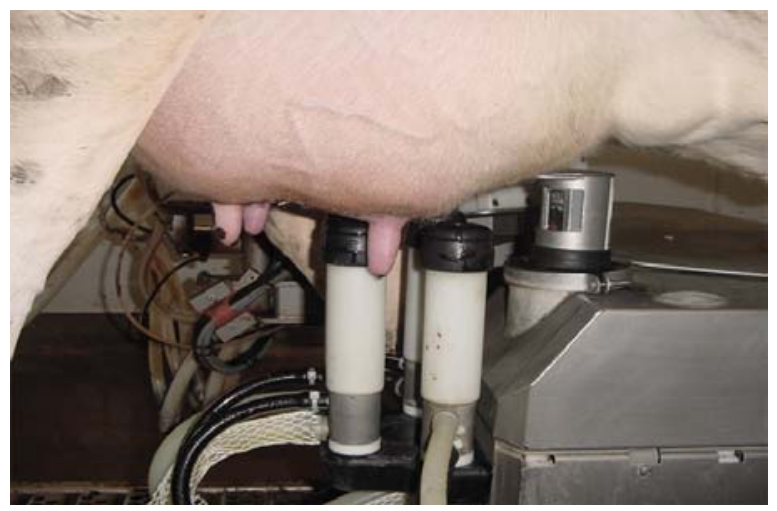

Şekil 1. Algılayıcılar yardımıyla meme başlarının seçimi (http://www.bae.uky.edu/ext/Livestock/dairy/milking.htm) 
işletmede problemli olan ineklere uygulama yapması gerekmektedir (De Koning ve ark.2001, Graves 2002, Reinemann ve ark. 2002).

c) Robot kol: Farklı tipte robot kolları robotlu sağım sistemlerinde kullanılmaktadır (Rossing ve ark. 1997, De Koning ve ark. 2001). Çok duraklı sağım sistemlerinde hareket edebilir bir robot kol bulunmaktadır. Sağım cihazı ve robot kol ayrı birimlerdir. Her bir sağım durağı özel bir raf üzerine monte edilmiş dört sağım başlığına sahiptir. Robot kol bir duraktan diğerine doğru hareket etmektedir. Her bir sağım başlığı ayrı ayrı takılmaktadır. Sağım başlıkları takıldıktan sonra, robot kolun bağlantısı kalmamaktadır ve diğer durağa doğru hareket etmektedir. Diğer bir sistemde robot kol ile bütünleşen sağım durağında bir robot kolun kullanımı şeklinde olmaktadır (De Koning ve ark. 2001).

Bütün sistemler için, robot kol üzerinde yer alan sağım başlıkları dört meme başına birbirini izleyen sırada takılmaktadır. Sağım başlığı ilk önce 4 meme başından arka meme başlarına takılmakta ve daha sonra da ön meme başlarına takılarak işlem tamamlanmaktadır. Genel olarak takma işlemi 45 ile 100 saniye arasında sürmektedir. Bu süre robotlu sağım sistemi ile ineğin meme özelliklerine ve davranışlarına bağı olmaktadır (De Koning ve ark. 2001). Şekil 2'de sağım yapılırken robot kolun yandan görünüşü ve Şekil 3'de de bir robotlu sağım sisteminde ineklerin sağıldığı sağım durakları görülmektedir.

d) Sağım durağı: Sağım durağı ineğin durduğu ve zapt edildiği yerdir. Keza durak, robotun manevra yapma kabiliyetine sahip olan kolunun bulunduğu, yem verildiği, giriş ve çıkış kapılarını içeren farklı aksesuarların monte edilmesi gibi çeşitli konularda hizmet vermektedir (Graves 2002).

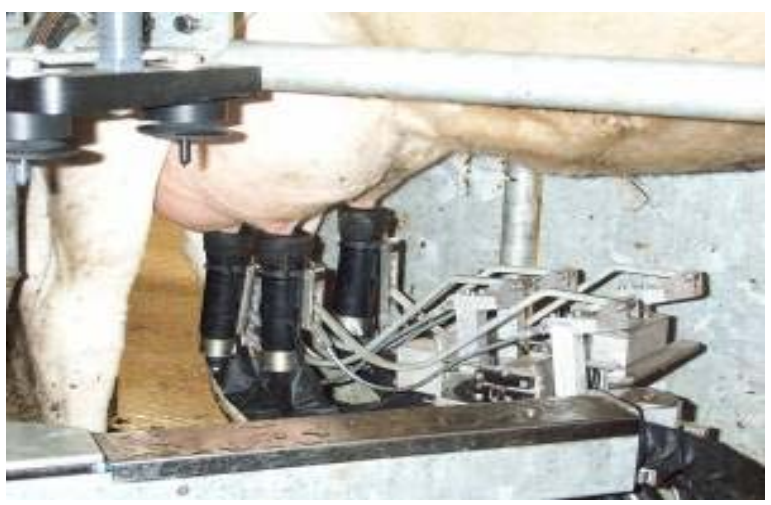

Şekil 2. Sağım yapılırken robot kolun yandan görünüşü (http://www.uwex.edu/uwmril/robot/photos/rpmain.htm)

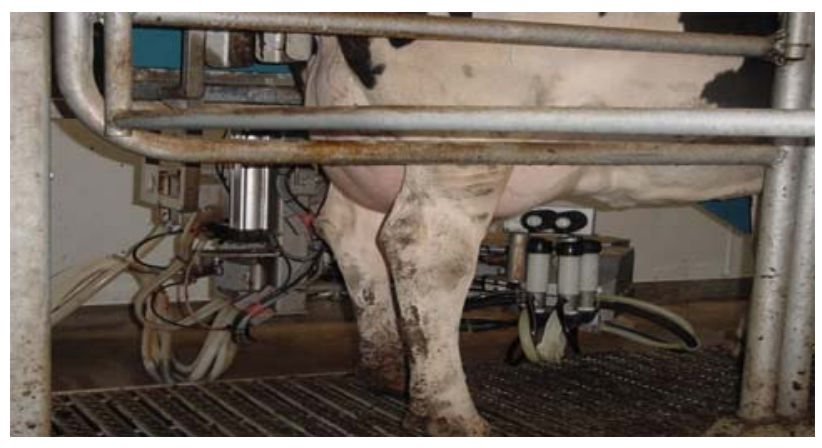

Şekil 3. Bir robotlu sağım sisteminde ineklerin sağıldığı sağım durakları

(http://www.uwex.edu/uwmril/ robot/photos/rpmain.htm)

e) Otomatik kapılar: Elektrikle çalışan otomatik kapılar, sisteme ait olan sağım durağına giriş ve çıkış noktalarında bulunmaktadır. Sağım durağından önce ya da sonra bulunan bu kapılar ineğin sağım durağında tutulması ya da sağım durağı çıkışında kullanılmaktadır. Ağırık ya da yay ile çalışan tek yönlü giriş kapısı, inek hareketinin kontrolü için kullanılmaktadır (Graves 2002).

f) Yemleme yeri: Bütün robotlu sağım sistemlerinde sağım durağında yemle beslemenin yapıldığı bir yemleme kısmı bulunmaktadır. Yem sağım süresince ineğin sakince durmasını ve ineğin sağım durağına dürtü oluşumu sonucunda gitmesini sağlamaktadır (Graves 2002).

g) Temizleme sistemi: Sağım hijyeninin amacı; elde edilen sütün ve memenin temiz olması, sağım makinesinin etkili ve verimli bir şekilde kullanılmasıdır (Guterbock 1984).

Sağım öncesinde ve sonrasında meme ile sağım başlıkları, süt hortumları, ölçekli süt toplama kavanozu, süt iletim boru hattı ve süt toplama tankının temizlenmesi ve durulanması gerekmektedir. Meme başlarının yıkanmasının başlıca amacı süte bulaşabilen kir ile diğer zerrelerin uzaklaştırılmasıdır. Meme başı temizleme sistemi inekten ineğe ya da bir meme başından diğerine memedeki patojenlerin taşınma riskini azaltmayı amaçlamalıdır (Graves 2002, De Koning ve ark. 2001). Şekil 4'de Robotlu sağım sisteminde fırçalarla meme ve meme başlarının temizlenmesi görülmektedir.

Robotlu sağım sistemleri ile meme başlarının yıkanması;

1. Silindirler ya da fırçalar ile birbiri ardına meme başlarının temizlenmesi, 


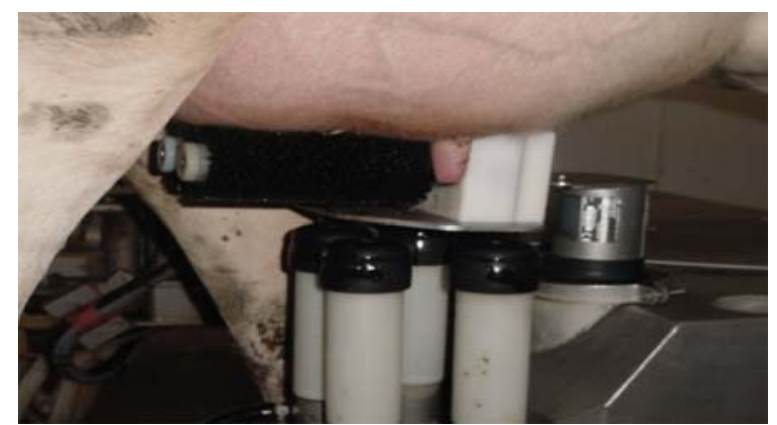

Şekil 4. Robotlu sağım sisteminde fırçalarla meme ve meme başlarının temizlenmesi

(http://www.uwex.edu /uwmril/robot/ photos/rpmain.htm)

2. Dairesel dönen bir fırça tarafından eş zamanlı temizleme,

3. Sağım başlığına benzer ayrı bir aygıt içinde yıkama şeklinde olabilmektedir.

Sağım ekipmanları sağımda kullanıldıktan sonra süt kalıntıları, yağ, protein ve mineral maddeden oluşan kurumuş bir tabakayla kirlenmektedir. Temizlik amacıyla kullanılan solüsyonlar, süt kalıntıları ve yağların sağım ekipmanlarından temizlenmesine yardımcı olmaktadır (Clegg 1962).

Süt hortumu ve sağım başlıkları da her sağımdan sonra su püskürtülerek durulanmaktadır. Eğer inek sütü herhangi bir tedaviden dolayı ilaç kalıntıları içeriyorsa, bu sütün temas ettiği ekipmanların (ölçekli süt toplama kavanozu, süt hortumları ve sağım başlıkları) temizlenmesi gerekmektedir. Önceden tespit edilen zamanda (günde 2 ya da 3 defa) bütün sistem tamamen yıkanmaktadır. Depolama tankları, süt tanktan uzaklaştırılıktan sonra yıkanmaktadır. 2 tank kullanıldığı zaman, ara bağlantı, otomatik valflar, temizleme ekipmanı ve temizleyici solüsyonla temizlenmektedir (Graves 2002).

h) Sağım sistemi: Robotlu sağım sisteminde, sağım işini yapan ekipmanlar, bir süt iletim hattı, süt akışı algılayıcıları, süt ölçüm kavanozu ile sağım başlıklarından meydana gelmektedir. Süt ölçüm kavanozu, inekten alınan sütün toplanmasında kullanılmaktadır (Graves 2002).

Robotlu sağım sisteminde, inekler sistemi gönüllü olarak ziyaret etmektedir. İnek sağım ya da yem yemek için doğrudan tanımlama durağına gitmektedir. İnekler robotlu sağım sisteminin sağım durağına geldiği zaman sistem çalışmaya başlamaktadır. Sağım sisteminin bilgisayarı inekleri tanımaktadır, bu genellikle ineklerin boynunda bulunan manyetik tasmalar sayesinde olmaktadır ve tanınan ineklerde sağım işlemi başlatılmaktadır. Sistemin giriş kapısı elektronik olarak kapandıktan sonra elektronik yemleyiciler ile yem verilmektedir. Sistemin bir parçası olan metal robot kol ineğin altına doğru gelmekte ve metal robot kolun üzerine monte olan yıkama sistemi ile meme başları temizlenmektedir. Yıkama işleminden sonra temizleme işlemini yapan silindir şeklindeki fırça geri çekilmektedir ve lazer ünitesi ile ineğin meme başlarının konumları belirlenmektedir. Lazer sistemle meme başlarının yerleri belirlendikten sonra metal robot kol üzerinde bulunan sağım başlıkları ineğin memesine takılmaktadır. Her bir sağım başlığı kendi ölçme aygıtına sahiptir. Süt akışı azaldığında sağım başlıklarındaki vakum azalmakta ve sağım başlıkları çıkarılmaktadır. Bütün sağım başlıkları çıkarıldıktan sonra, metal robot kol üzerinde her sağım başlığı yıkanmakta, metal robot kol tekrar ineğin altına doğru hareket etmekte ve her bir meme başına dezenfektanlı solüsyon püskürtülmektedir. $\mathrm{Bu}$ işlem de tamamlandıktan sonra çıkış kapıları açılmakta ve inekler sağım durağından ayrılmaktadır (Halladay 1999, Cooper 2001, Gearin 2001, Dick 2002, Hopster ve ark. 2002, Rodenburg 2002, Radfor 2003, Wilson 2003, Halachmi 2004, Anonymous 2005a). Şekil 5 'de sağım başlıklarının takılması ve Şekil 6'da sağım işlemi yer almaktadır.

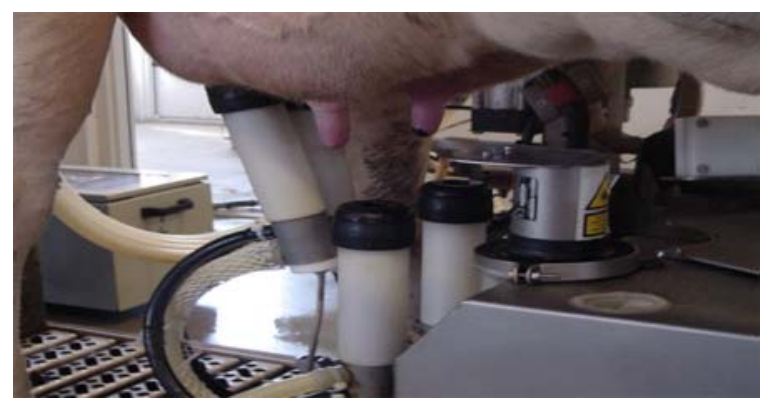

Şekil 5. Sağım başlıklarının takııması (http://www.uwex.edu/uwmril/robot/photos/ rpmain. htm)

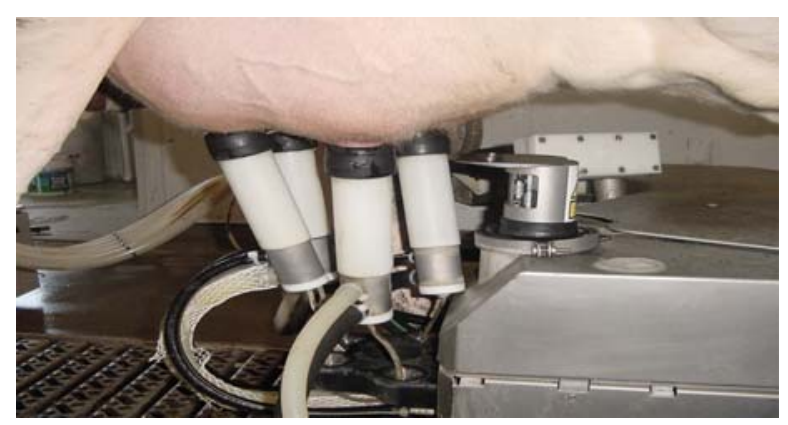

Şekil 6. Robotlu sağım sisteminde sağım işlemi (http://www.uwex.edu/uwmril/robot/photos/rpmain.htm) 
İşletme sahipleri robotlu sağım sistemini kullanarak yüksek süt kalitesi elde etmektedir. Ancak, bazı yönetim stratejileri geleneksel bir sağım sistemine göre farklı olmaktadır. Örnek olarak, mastitis kontrolü, geleneksel sağım sistemlerinde kuru meme başları için bir kurulama servisini ve sağımdan sonra enfekte olmayan bir meme için daldırma işlemini gerektirmektedir (Radfor 2003). Diğer taraftan bir robotlu sağım sisteminde meme başları otomatik olarak kurulanmakta, sağımdan sonra daldırma yerine bir sprey kullanılarak aynı işlemler yapılmaktadır (Radfor 2003).

Robotlu sağım sisteminde hem inek hem de sistemin performansını dikkatli bir şekilde denetlemek ve sağım sisteminin nasıl denetleneceğinin öğrenilmesi bakımından işletme sahibine bir takım sorumluluklar düşmektedir. Robotlu sağım ünitesini gönüllü ziyaret etmeyen inekler düzenli bir şekilde sağıma yönlendirilmelidir.

I) Sütün soğutulması ve depolanması: İnekten sağım başlıkları ile alınan sütün hem soğutulması hem de sütün depolanması için önce süt ölçerlere daha sonra da süt toplama tankına transfer edilmesi gerekmektedir (Graves 2002).

Süt soğutma ve depolama sistemleri birçok otomatik sağım sisteminde olduğu gibi robotlu sağım sisteminde de kullanılmaktadır. Depolama sistemi herhangi bir zamanda kullanılabilmektedir. Çünkü inekler herhangi bir saatte sağım bölmesine gelebilmektedir. Sütün toplanmasına ve sonradan tankın temizlenmesine yardımcı şekilde çalışma durumu için mevcut ikinci bir tank bulunmaktadır. Küçük bir süt akışının zamanında soğutulması gerekmektedir. Soğutma sistemi çok geniş ve uzun bir tanka sahiptir ve yeterli miktarda toplanan sütün uygun soğutulması için soğutma levhaları ile kaplanmıştır. Bundan dolayı, sütün toplanmasında kullanılan yardımcı tank, genellikle sütün küçük miktarlarda hızl bir şekilde soğutulmasını sağlayan küçük bir tanktır. Küçük tanka yeterli miktarda süt geldiği zaman geniş tank tam anlamıyla soğutulmaktadır ve bu aşamadan sonra süt esas tanka transfer edilmektedir (Graves 2002).

Robotlu sağım ile ekonomi ve işgücü : Geleneksel olarak, işletme sahipleri kendi gelecekleri için, sermayenin büyümesine güvenerek ve kendi arazilerinde çeşitli üretimler yapmaktadır. Süt sığırcılığı içerisine işletme sahiplerini çeken, süt fiyatları dengede olduğunda, az bir parasal yatırımla süt sığırcılığı işletmesine sahip olabilmek ve bu bakış açısına güvenmektir (Creamer ve ark. 2002).
Gelişen ülkelerde büyük işletmeler dışında küçük işletmeler kültürel ve diğer sebepler nedeniyle yavaş yavaş etkinliğini yitirmeye başlamaktadır. Tek bir aile işletmesi ekonomik bakımdan varlığını sürdürememektedir. Süt sığırcılığına olan eğilim, inek sayısının fazla olduğu işletmelerde ya da 200 ile 500 baş inekten tipik olarak sağım yapılan işletmelerde, ek olarak işgücü kullanımı ile bir aile ünitesi etrafında yürütülmeye çalışılmaktadır. Gelecekteki eğilimlerin, geniş bir sürü formatına geçiş ve tek aile birimleri içinde bir azalma şeklinde olması beklenmektedir (Creamer ve ark. 2002).

İşletme genişliği artışı nedeniyle, işletmedeki işgücü önemli bir konu olmaktadır. Bazı durumlarda, işçiler sağımın üstesinden gelmek için kendine özgü bir şekilde çalıştırılmaktadır. Ancak işgücü maliyetinin yüksek olduğu bazı ülkelerde bu durum problem haline gelmiştir. Bunun için mevcut işgücünü azaltmak amacıyla günlük sağım sıklığını azaltma yoluna gidilmiştir (Hogeveen ve ark. 2000a, Hogeveen ve ark. 2000b, Hogeveen ve ark. 2001, Creamer ve ark. 2002) Ancak bu şekilde sağım sıklığının azaltımasının, inek başına üretimde önemli bir azalmaya neden olduğuna işaret edilmektedir (Creamer ve ark. 2002).

İşgücünden tasarruf, idari görevleri yoğun olan küçük işletme yöneticilerine yardımcı olmaktadır. Bu son derece önemlidir. İyi bir idare sonucunda işletmeye dönen ekonomik faydalar, sağımdan sonra geriye dönen faydadan daha büyüktür. Buradaki problem küçük işletme yöneticilerinin kendi yerlerine bakan personelin denetlenmesi, ürünlerin hasat edilmesi ve ineklerin sağılması gibi zaman gerektiren işler yüzünden işletme idaresine yeterince vakit ayıramamasıdır. Sonuç olarak küçük işletmelerin yöneticileri, mümkün olan en iyi kararları alabilmek için finansal kayıtlar ile üretim analizi yapmak için zaman bulamamaktadır (Hyde ve ark. 2002).

Son teknoloji ile geliştirilmiş olan robotlu sağım sisteminin en büyük yararı, iyi hesaplama ve yönetim becerileri olan özellikle genç insanlar için daha fazla sosyal aktiviteye olanak veren bir süt sığırcılığı yapmaktır. Her ne kadar yapılan çalışmalar iş gücünün \%30-40 kadar azaltıldığını bildirse de pratikte bu \% 10 kadar olmaktadır. Bu değişim tatminkar olmakla birlikte işletme içerisinde iş yapmak da gereklidir. İlk olarak, sürü yönetimi daha az zaman almaktadır. Böylece iş gücü daha esnek olmaktadır. İkinci olarak, haftada 14 defa yada daha fazla yapılan sağımın rutin görevleri bir bilgisayar kontrolünde yerine getirilmekte ve sağım zamanında inekler düzenli bir şekilde izlenebilmektedir (Klindworth 2003).

Sağım, tekrarlanan, sağımcının sağlık riski taşıdığı bir iştir (Gustafsson ve Lundgvist 1987, 
Lundgvist ve ark. 1997, Reinemann 2005a). Geleneksel sağım sistemlerinde makineli sağım yapan kişinin diz, kalça ve aşağı arka eklem yerleri üzerinde devamlı baskı meydana geldiği tespit edilmiştir (Reinemann 2005a). Geleneksel sağım sistemlerinde bedenin çalışma esnasında duruşu, doğal çalışma pozisyonunda eller ve kollar ile dimdik duracak şekilde olunmasına dikkat edilmelidir (Gaudin ve ark. 1998)

El ve bilek problemleri sağım yapan kişilerde yaygın olarak görülmektedir. Yapılan bir çalışmada makineli sağım süresince bileklerin hareketleri ve pozisyonları ölçülmüştür. Değerlendirmeye alınan 7 sağımcının sağ ve sol bileklerinde esneklik azalmas tespit edilmiştir. El ve bilek semptomlarında yüksek derecede sırta doğru bükülme ve merkezden sapma olduğu bulunmuştur. Bundan başka, tekrar gerektiren işlerde bilek ve dirsek rahatsızlıklarının yüksek risk oluşturduğu tespit edilmiştir. İşletmeye yeni bir sistem kurulduğu zaman, bileklerin hareketleri ile pozisyonlar üzerine yeni sağım sistemlerinin etkilerinin olumsuz olmadığı gözlemlenmiştir (Dijkhuizen ve ark. 1997, Pinzke ve ark. 2001, Stal ve Juliszewski 2001, Graves 2002, Hyde ve ark. 2002, Hopster ve ark. 2002, Vorst ve ark. 2003).

Robotlu sağım sisteminin, süt sığırcılığı işletmecilerince niçin talep edildiği araştırıldığında finansal olmayan nedenler önem kazanmaktadır. Finansal olmayan yönler çoğunlukla işgücü ile ilgilidir. Bu konu üzerinde yapılan araştırma sonuçları, robotlu sağım sistemi kullanımının nedeni işgücü ve miktarından tasarruf sağlanması olduğunu ortaya koymuştur (Dijkhuizen ve ark. 1997, Graves 2002, Vorst ve ark. 2003).

Yapılan araştırmalara göre robotlu sağım sistemleri farklı sebeplerden dolayı işletme içerisine kurulmaktadır. Bunları 2 başlık altında toplayabiliriz:

Sosyal sebepler: Hayvan refahı, sosyal yaşamın geliştirilmesi, sağlık problemleri ki özelikle yaşlı işletme sahipleri için yada fiziksel sağlık problemleri olanlar için daha az fiziksel çalışma imkanının sağlanması, diğer aktiviteler üzerine daha fazla vakit harcamak, işgücü yoğunluğunun azaltılması vb.,

Ekonomik sebepler: Süt üretiminin arttırılması, daha az gübre üretimi, daha fazla idari bilgiye sahip olma, inek ve meme sağlığını iyileştirme, işletmeyi büyütme, işçi sayısını azaltma, günde 2 defadan daha fazla sağım yapma başlıca ekonomik nedenlerdendir (Artman 2001, Meskens ve Mathijs 2002, Klindworth 2003).
Robotlu sağım ve süt üretimi : Ticari işletmelerde sağım aralığı farklılık göstermekle birlikte günde ortalama 2 ile 3 sağım yapılmaktadır. Robotlu sağım sistemlerinin başlıca yararlarından birisi, sağım sıklığındaki artışa bağlı olarak, süt üretiminde bir artış olmasıdır (Erdman ve Varner 1995, Ouweltjes 1998, De Koning ve Ouweltjes 2000, Kruip ve ark. 2000, Kruip ve ark. 2002, Wagner-Storch ve Palmer 2003). Sağım günde 2 ya da 3 'den sağımdan daha sık yapıldığında, tamamlanmış laktasyonlarda süt üretiminde \%6 'dan \%25'e kadar artış tespit edilmiştir (Amos ve ark. 1985, De Peters ve ark. 1985, Allen ve ark. 1986, Erdman ve Varner 1995, Klei ve ark. 1997, Hogeveen ve ark. 2000b, Baines 2004). Bu şekilde çeşitli çalışmalar da mevcuttur. İsveç'de yapılan bir çalışmada robotlu sağım sisteminin işletmeye girmesiyle birlikte süt üretiminde meydana gelen artışın \%6.75 olduğu bildirilmiştir. Danimarka'da yapılan çalışmada ise süt üretiminde günde 23.9 'dan $24.4 \mathrm{~kg}$ kadar \%2 lik bir artışın olduğu saptanmıştır. Yine Hollanda'da yapılan bir çalışmada robotlu sağım sistemine geçiş ile süt üretiminde \%11.4'lük bir artış olduğu saptanmıştır (Baines 2004).

Birim süt üretimi başına masrafların azaltılması ve robotlu sağımın en yüksek kapasitede kullanılması için işletme yönetimi ineklerin idaresi, beslenme, ahır koşulları ile hayvan sağlığı üzerine odaklanmalıdır (De Koning ve Ouweltjes 2000).

Robotlu sağım ve süt kalitesi : Sütün kalitesi süt üretimi bakımından çok önemlidir. Süt fiyatlandırma sistemleri ve tüketici istekleri, oldukça geniştir ve süt üretiminde esas oluşturmaktadır. (Billon 2001, Klungel ve ark. 2000, Hogeveen ve ark. 2000a, Justesen ve Rasmussen 2000, Pomies ve Bony 2000, Van der Vorst ve Hogeveen 2000, Rasmussen ve Madsen 2000).

Sığırlardan elde edilen iki temel üründen biri süttür. Çok değişik koşullarda oldukça farklı işlenebilen sütün temel özelliklerinden birisi muhafazasının özel koşullar gerektirmesi ve uzun süreli olmamasıdır (Akman ve ark. 2005). Çünkü düşük sıcaklıklarda bakteri içeriğinin artması engellenmektedir (De Koning ve ark. 2002). Bundan dolayı, bir işletmede sağımın tamamlanmasının ardından süte derhal bir ön soğutma yapılması gerekmektedir (Reinermann 2002).

Robotlu sağımın kullanıldığı işletmelerde de süt kalitesi üzerinde durulması gereken bir konudur. Robotlu sağım tamamen otomatik yöntemlerle yapılmaktadır. Geleneksel sağım sistemlerinde sütün görsel kontrolü, sağım süresince mümkün olmamaktadır. Bundan dolayı, süt kalitesinin farklı 
bir biçimde kontrol altına alınmasına gereksinim duyulmaktadır. Robotlu sağım sisteminde süt iletkenliği, renk ve sıcaklık algılayıcılar gibi çeşitli aygıtlar, süt verimi ölçümü sistem tarafından oluşturulan çizelgelerin bir araya getirilmesi ile inek ve sütün durumu hakkında işletmecinin bilgilendirilmesi sağlanmaktadır (Lind ve ark. 2000, Reinemann ve Smith 2000, Justesen ve Rasmussen 2000, Klungel ve ark. 2000, Pomies ve Bony 2000 , Van der Vorst ve Hogeveen 2000, Billon 2001, Reinemann ve Helgren 2004). Bununla birlikte, daha önceden yapılan çalışmalarda, robotlu sağım sistemi kurulan işletmede kurumdan kısa bir zaman sonra, süt kalitesi ile mastitis seviyesinde kötüye gidiş eğilimi olduğu saptanmıştır. Kötüye gidişin kapsamı, genelde sistem değişimi öncesinde sürü içindeki mastitis kontrolü ve idarenin etkisiz olması ile ilişkilidir (Baines 2004).

Geleneksel sağım ile robotlu sağım sistemleri, sağım öncesi ve sonrası meme başlarının temizlenmesinin sütteki toplam bakteri içeriğine etkisi bakımından karşılaştırılmıştır. Karşılaştırma sonucunda, bakterilerin \%65'inin geleneksel sağım sistemi ile ve \%95'inin de robotla sağım sistemleri ile uzaklaştırıldığı tespit edilmiştir.(Melin ve ark. 2004).

Somatik hücre sayısı da önemli süt kalite parametreleri arasında yer almaktadır. Yapılan çalışmalar sağım sıklığının sütün somatik hücre sayısına pek etkisi olmadığını göstermektedir (Kruip 2002). Ancak işletmelerde uygulanan sağım sistemlerinin sütün somatik hücre sayısına etkisi olduğu ve özellikle robotlu sağım sisteminin somatik hücre sayısı üzerinde azaltıcı bir etkiye neden olduğu bildirilmektedir (Schukken 1999, Kruip 2000, Helgren ve Reinemann 2003)

Sütün asitliği, sütteki serbest yağ asidi miktarındaki artıştır. Sağım sıklığı sütün asitliği üzerine etki etmektedir (keza günde 3 sağımın yapıldığı geleneksel sağım sistemlerinde sütün asitliği yüksek olmaktadır) ve robotlu sağım sisteminde de bu etk bulunmaktadır (Ipema ve Schuiling 1992).

İşletmelerde yapılan çalışmalarda çoğu işletme suyunun bakteri ile bulaşık olduğu tespit edilmiştir. Sağım ekipmanlarının yıkanmasında bakteri ile bulaşık suyun kullanılması durumunda hastalıkların ortaya çıktığı bildirilmiştir. Eğer su bakteri ile bulaşık ise, bu su ile temizleme yapılması süt kalitesini azaltıcı bir etkiye neden olmaktadır. Temizlik ve durulama için robotlu sağım sistemlerinde kullanılan suyun kontrol edilmesine rağmen, otomatik sağım sistemlerini kullanan işletmelerin gerekli önlemleri alması tavsiye edilmektedir (Schukken ve ark.1999, Meijering 2004).
Süte kir, mikroorganizma vb. bulaşmasının önlenmesi için, yılda bir kez meme başı temizleme ekipmanlarının değiştirilmesi, sağım ekipmanlarının yeterince temizlenmesi gerekmektedir (Knapsstein ve ark. 2004a, Knappstein ve ark. 2004b). Robotlu sağımda temizleme sistemi robotla bütünleşen diğer sistemlerdeki gibi temizleme işini otomatik olarak yapmaktadır. Bundan dolayı süte olan bulaşma en aza indirilebilmektedir. Bunun yanında robot tarafından meme sağlığı uygun olmayan inekler tespit edilip sağıma alınmamaktadır.

Robotlu sağım ve hayvan sağlığı: Bir süt sığırcılığı işletmesinde uygulanan sağım sistemi işgücü, süt verimi ve kalitesi gibi unsurların yanında inek sağlığı üzerine de etki etmektedir. Süt sığırlarında, mastitis benzeri hastalıkların tespitinde yeni teknolojilerin kullanımı, özellikle sağım boyunca yapılan gözlemlere bir alternatif oluşturmaktadır.

Sütteki somatik hücre sayısı, meme sağlığının korunması için üzerinde durulan bir parametredir. Somatik hücre sayısı, aylık süt kontrollerinde tespit edilmektedir (Barth 2001). Sütteki somatik hücre sayısı 300.000 hücre/ml'den yüksek çıktığında mastitis riski ortaya çıkmaktadır (Pallas ve Wendt 2001). Yapılan araştırmalar somatik hücre içeriğinin robotlu sağım sistemleri için bir problem oluşturmadığı yönündedir. Robotlu sağım sistemi işletmede kullanılmadan önce birçok işletmede elde edilen süt içeriğinde somatik hücre sayısının yüksek düzeyde olduğu, ancak kısa bir süre sonra sağım sisteminin değiştirilmesine paralel olarak azaldığı tespit edilmiştir (Schukken ve ark.1999, Berglund ve ark. 2002, Täubert ve ark. 2004).

Mastitisi teşhis etmek için kullanılan geleneksel metotlarla, enfekte olan meme başları tam olarak belirlenememektedir. Ancak robotlu sağım sistemlerinin kullanıldığı işletmelerde süt kalitesi ve hayvan sağlığı için sistem bilgisayarı tarafından yapılan rutin kontroller sayesinde meme ve meme baş sağığı güvenilir bir şekilde kontrol edilebilmektedir (Koehler ve ark. 2002).

Mastitis bulaşma oranı, sağım başlıkları çıkarılmadan önce bir ya da daha fazla sağım başlığı içine aniden hava girişi olduğunda makine çalışma şekli ile artmaktadır. Bundan başka, sağım pençesi üzerine ekstra vakum yüklendiğinde, sağım başlıklarının meme başlarına olan basıncı artmakta ve onların dengesi sağım pençesini etkilemektedir. Sağım başlıklarının basınç frekansındaki artış mastitis riskini arttırmaktadır (Graeme 2001). Bunun yanında, çoğu mastitis enfeksiyonunda artışa vakum almacı ya da dengesiz süt iletim hattı arasındaki ilişkiler ile sağım makinesindeki diğer faktörlerin sebep olduğu bildirilmiştir (Reinemann 2005b). Sağımda meme 
başlarına uygulanan düşük vakum ve kaplama maddesinin iç cidarına gelen vakum sıklığı, süt verimi yüksek olduğunda, meme başı kondisyonunu ve meme sağlığını etkilememektedir, sadece yavaş sağım süt verimini \%5 oranında azaltmaktadır (Rasmussen ve Madsen 2000). Sağım performansındaki başlıca problem, meme başının sonuna uygulanan düşük vakumun sağım başığının plastik astarının iç yüzünde artması ve rutin sağım işinin bozulmasıyla sağımda düşüş meydana gelmesidir. Sağımda meme başlarına yüksek vakum uygulandığında ise, meme başlarının yıpranmasına, meme başlarında kan birikmesine neden olmakta (Hamman ve ark. 1993) ve meme başlarının sonunda aşırı keratinleşme şekillenmesine neden olmaktadır (Rasmussen ve ark. 1993, Mein ve ark. 2003). Ancak robotlu sağım sistemlerinde vakum düzeyi bilgisayar tarafından ayarlandığından bu tür problemlerle karşılaşılmamaktadır.

\section{Sonuç}

Robotlu sağım teknolojisinin toplum tarafından desteklenmesi için iyi sebepler vardır. İlk olarak, robotlu sağım devlet ekonomisine yararlı olacaktır ve işlere yüksek oranda yarar sağlayacaktır. Robotlu sağım, süt sığırcılığı işletmelerinde birçok ailenin geçim sağlamasını ve aile işletmelerinin desteklenmesini sağlamaktadır. Bu teknoloji, kırsal bölgelerdeki ineklerin elde tutulmasını ve birbiri ardına gelen koku, kirlilik ve hayvanın refahıyla ilgili problemlerin ortadan kalkmasına yardımcı olacaktır. Ahır içerisine kurulmuş bir robot, ineklerin günlük alışkanlıkları üzerinde daha fazla kontrollerin yapılmas ile inek refahının geliştirilmesini sağlamaktadır. Bunun yanında, robotlu sağım işletmeye kurulduğu zaman inekler sisteme oldukça hızlı bir şekilde uyum göstermektedir. Çalışan personel de inekler kadar iyi bir şekilde sisteme uyum sağlamaktadır. Üretim önemli derecede artmakta, inek ve meme sağlığı da olumlu etkilenmektedir.

Robotlu sağım teknolojisi, süt sığırcılığı işletmelerinin gelişimine destek olacak ve yeni yönetim stratejilerini ortaya çıkmasına yardımcı olacaktır. Büyük sürülerde, sağım başlıklarının otomatik olarak takılması, gönüllü sağıma katılımın sağlanmasıyla robotlu sağım sistemlerine gelecekte başvurula bilinecektir.

Yeni teknolojiler kullanımının yaygınlaştırılması, tüketicilerin süt ürünlerine olan güvenini arttıracaktır. Kimya, fizik, elektronik ve haberleşme bilimleri ve teknolojilerinde ilerlemeler, tüketici hedeflerinin desteklenmesi ve karmaşık gıda sistemlerinin artışı büyük ölçüde anlaşılır hale gelecektir.
Yakın bir gelecekte süt üretiminin ekonomik anlamda karlı ve cazip olması ancak yoğun olarak bilgi teknolojilerinin kullanımı ile mümkün olacaktır.

\section{Kaynaklar}

Akman, N. 2003. Pratik Sığır Yetiștiriciliği. s. 35-48. II. Baskı, Türk Ziraat Mühendisleri Birliği Vakfı Yayını, Ankara,

Akman, N., S. Tuncel, S. M. Yener, S. Kumlu, K. Özkütük, N. Tüzemen,M. Yanar, M. Koç, O. Şahin ve Ç. Y. Kaya. 2005. Türkiye'de Sığır Yetiştiriciliği. Türkiye Ziraat Mühendisliği VI. Teknik Kongre. 687-706. 3-7 Ocak 2005, TMMOB, Ziraat Mühendisleri Odası, Ankara.

Allen D. B., E. J. De Peters. and R. C. Laben. 1986. Three times a day milking: effects on milk production, reproductive efficiency and udder health. Journal of Dairy Science 69:1441-1446.

Anonim. 1986. Süt Sağım Makinelerinin Deneyleri. Ts 4749/Mart 1986 UDK 631.223.016 Türk Standartları Enstitüsü, Ankara

Anonim. 2002. Hayvan Yetiştiriciliği IV. http:// www.tb-yayin .gov.tr/basili/2002/ hayvan_yetistiriciligi_IV_orta.htm

Anonymous. 2004. Automatic milking. Project Information. Research Institute for Animal Husbandry. http://www.automaticmilking.nl/index.asp?projectinform ation/general.asp

Anonymous. 2005a. Device Profile: DeLaval Voluntary Milking System (Oct. 21, 2005). http://www.linuxdevices. com/articles/AT8308307720.html

Amos, H.E., T. Kiser and M. Loewenstein. 1985. Influence of milking frequency on productive and reproductive efficiences of dairy cows. Journal of Dairy Science 68:732-739

Artman, R. 2001. The effects of automatic milking with single box facilities on animal behaviour and milk performance on larger farms. Physiological and Technical Aspects of Machine Milking. ICAR Technical Series No:7, p. 159164. Nitra, Slovak republic, 26-27 June 2001.

Baines, J. 2004. Managing the Change to a Robotic Milking System. http://www.milkproduction.com/article.asp?NSI0208

Barth, K. 2001. Evaluation of somatic cell count under automatic milking conditions. Physiological and Technical Aspects of Machine Milking. ICAR Technical Series No:7, p. 165-169. Nitra, Slovak republic, 26-27 June 2001.

Berglund, I., G. Pettersson and K. Svennersten-Sjaunja. 2002. Automatic milking: effects on somatic cell count and teat end-quality. Livestock Production Science 78:115-124. 
Billon, P. 2001. Les robots de traite en France; impact sur la qulité du lait en le système de production,, In: Proceedings: II Robot di Mungitura in Lombardia; Cremona, Italy

Cleg, L. F. L 1962. Cleaning and sterişliztion of milking equipment on the farm. (In): Milk hygiene. World Healt Organization (WHO). Geneva.

Cooper, K. 2001. Milking by Robots-Stimulating the Robotic Milking Farm. Operational Research Society. http://www.orsoc.org.uk/about/topic/insight/milk

Creamer, L. K., L. E. Perace, J. P. Hill and M. J. Boland. 2002. Milk and Dairy Products in the 21st Century. Journal of Agricultural and Food Chemistry 50 (25).

De Koning, K. and W. Ouweltjes. 2000. Maximising the milking capacity of an automatic milking system. International Symposium Robotic Milking 2000 http://www.automaticmilking.nl/

De Koning, K. V. Vorst and A. Meijering 2001. Automatic Milking Experience and Development in Europe. http://www.milkproduction.com

De Koning, K., J. Vestappen-Boerekamp and E. Schuiling. 2002. Milk Cooling Systems for Automatic Milking. Proc. First North American Conference on Robotic Milking, pp: 25-V35. March 20-21, 2001, Toronto, Ontario, Canada.

De Peters, E.J., N. E. Smith and J. Acedo-Rico. 1985. Three or two times daily milking of older cows and first lactation cows for entire lactations. Journal of Dairy Science 68:123-132.

Dick, G. 2002. Free Access Robotic Milking: The Next Generation?. Proceeding of the British Mastitis Conference (2002) Brockworth. P: 63-67. Institute for Animal Health/Milk Development Council.

Dijkhusen, A., R. Hurine, S. Harsh and R. Gardner. 1997. Economics of Robot Application. Computers and Electronics in Agriculture 17:111-121.

Erdman, R. A. and M. Varner. 1995. Fixed Yield Responses to Increased Milking Frequency. Journal of Dairy Science 78:1199-1203.

Gaudin, V., P. Billon and O. Sauvee. 1998. What kind of milking parlor for efficient and comfortable working conditions? Rencontres Rechercers Ruminants 5:321326.

Gearin, M. 2001. Robot Revolution for Dairy Industry.First Published: 21/01/2001, Australia's National Rural Affairs Weekly, Landline.

Graves, R. E. 2002. A Primer on Robotic Milking Systems. College of Agricultural Sciences, G105.
Graeme, M. 2001. Complereness of milking. http://www.umex.edu/pdf/milkmachine/performancetesti ng /completeness_of_milking_Aug01.pdf

Gustafsson, B. and Lundgvist, P. 1987. Working postures and human health problems in Swedish milk production. Latest Developments in Livestock Housing p: 118-126.

Guterbock, M. 1984. Practical Aspects of Mastitis Control in Large Dairy Herds. Part II. Milking Hygiene. Chino Valley Veterinary Associates Ontario, California. Continuing Education Article. 6 (11).

Halachmi, I. 2004. Designing the Automatic Milking Farm in a Hot Climate. J. Dairy. Sci. 87:764-775.

Halladay, D. 1999. Milking with robots? Not Your Grandpa's Milking Machine!. March, 1999. http://www.moomilk.com/archieve/tech_30.htm

Hamann, J., G. A. Mein and S. Wetzel. 1993. Teat tissue reactions to milking: effects of vacuum level. Journal of Dairy Science 76(4):1040-1046.

Helgren, J. M. and Reinemann, D. J. 2003. Survey of Milk Ouality on United States Dairy Farms Utilizing Automatic Milking Systems. ASAE Annual International Meeting Technical Paper. No. 033016. 27-30 July 2003, Nevada. USA.

Hogeveen, H., J. D. Miltenburg, S. Den Hollander and K. Frankena. 2000a. A longitudinal study on the influence of milking three times a day on udder health and milk production. p: 297-298 Ed: H. Hogeveen and A. Meijering. Robotic Milking, Proceedings of the International Symposium, Lelystad, The Netherlands.

Hogeveen, H., W. Ouweltjes, C. J. A. M. De Koning and K. Stelwagen. 2000b. Relationships between milk interval, milk yield and machine-on time. $51^{\text {st }}$ Annual Meeting of the European Association for Animal Production.

Hogeveen, H., Ouweltjes, W., De Koning, C.J.A.M. and Stelwagen, K. 2001. Milking interval, milk production and milk flow-rate in an automatic milking system. Livestock Production Science 72: 157-167.

Hopster, H., R. M. Bruckmaier, J. T. N. Van Der Werf, S. M. Korte, J. Macuhova, G. Korte-Bouws and C. G. Van Reenen. 2002. Stres Responses During Milking; Comparing Conventional and Automatic Milking in Primiparous Dairy Cows. J. Dairy Sci. 85: 3206-3216.

Hyde, J., P. Engel and B. Lang. 2002. Inversting in Robotic Milkers on North American Dairy Farms: Now. Later or Never?. Pennstate, 2002 March, Staff Paper p: 347.

Ipema, A. H. and E. Schuiling. 1992. Free fatty acids, influence if milking frequency. $p$ 491-496 in prospects for automatic milking. EAAP publication no. 65 . 
Justesen, P. and M. D. Rasmussen. 2000. Improvement of milk quality of by the Danish AMS self-monitoring program, Proceedings of the International Symposium Robotic Milking. P: 83-88. 17-19 August 2000, Lelystad, The Netherlands,

Klei, L.R., J. M. Lynch, D. M. Barbano, P. A. Oltenacu, A. J. Lednor and D. K. Bandler. 1997. Influence of milking three times a day on milk quality. Journal of Dairy Science 80:427-436.

Klindworth, D. 2003. Automatic Milking Installations. Cowtime Project, National Milk Harvesting Centre. Cowtime Ouick Note, 5.8, January 2003. http://www.cowtime.com.au/

Klungel, G.H., B. A. Slaghius and H. Hogeveen. 2000. The effect of the introduction of automatic milking on milk quality. J. Dariy Sci. 83:1998-2003.

Knappstein, K., N. Roth, J. G. Walte, J. Reichmuth, B. A. Slaghuis, R. T. Ferwarda-van Zonneveld and A. Mooiweer. 2004a. Effectiveness of automatic cleaning of udder and teats and effects of hygiene management. EU Project Automatic Milking, Deliverable D14.

Knappstein, K., N. Roth, J. G. Walte, and J. Reichmuth 2004b. Report on hygiene measures resulting in adequate teat cleaning. EU Project Automatic Milking. Deliverable D15.

Koehler, S. D., O. Kaufmann, J. McLean, M. Sinclair and B. West. 2002. Using Fuzzy Kogic to Control Udder Health in AMS. The First North American Conference on Robotic Milking, 11: 39-48. Toronto, Canada , March 20-22, 2002, Iv-39-Iv-48; 11 ref. s.

Kruip, T. A., J. Stefanowska and W. Ouweltjes. 2000. Robot Milking and Effecvt on Reproduction in Dairy Cows. Anim. Reprod. Sci., 60-61:443-7. 2000 Jul, 2.

Kruip, T. A. M., H. Morice, M. Robert and W. Ouweltjest. 2002. Robotic Milking and Its Effect on Fertility and Cell Count. J. Dairy Sci. 85:2576-2581.

Lind, O., A. H. Ipema, C. Koning, T. T. Motram and H. J. Hermann. 2000. 'Automatic Milking: Realities, Challenges and Opportunities. In 'Robotic Milking: Proc. of the International Symposium Held in Lelystad, p: 1931.the Netherlands, 17-19 August 2000, Wageningen Pres.,

Lundgvist, P., M. Stal and S., Pinzke. 1997. Ergonomics of cow milking in Sweden. J-Agromed 4(1/2): 169-176.

Meskens, L. and E. Mathijs. 2002. Socio-economic aspects of automatic milking. Motivation and characteristics of farmers investing in automatic milking systems. http://www.automaticmilking.nl/Projectresults /Reports/DeliverableD2.pdf

Mein, G.A., Williaös, D.M.D. and Reinemann, D.J. 2003 Effects of Milking On Teat-End Hyperkeratosis:1. Mechanical Forces Applied By the Teatcup Liner and Responses of the Teat. Proc. $43^{\text {rd }}$ Annual Meeting of the National Mastitis Council.
Melin, M.; H. Wiktorsson and A. Christianson. 2004. Teat Cleaning Efficiency Before Milking in Delaval VMS Versus Conventional Manual Cleaning. Automatic milking-Abetter understanding, 117. Wageningen, The Netherlands: Wageningen Academic Publishers.

Meijering, A. 2004. The International Symposium on Automatic Milking. Lelystad, March, 20-24. http://www.automaticmilking.nl/symposium.

Oostra, H. 2000. Combining Video Observations with Data Files from Automatic Milking. $3^{\text {rd }}$ International Conference on Methods and techniques in Behavioral Research, 15-18 August 2000, Nijmegen, the Netherlands.

Ouweltjes, W. 1998. The relationship between milk yield and milking intervail in dairy cows. Livestock Production Science 56:193-201.

Pallas, S. and K. Wendt 2001. The Development of udder health of a dairy cow herd in an automated milking system. Physiological and Technical Aspects of Machine Milking. ICAR Technical Series No:7, p. 175179. Nitra, Slovak republic, 26-27 June 2001.

Philpot, W.N. and S. C. Nickerson 1991. Mastitis Counter Attack, Babson Bros. Co. Illinois, U.S.A

Pinzke, S., Stal, M. and Hansson, G.A., 2001. Physical workload on upper extremities in various operations during machine milking. Annals of Agricultural and Environmental Medicine 8(1):63-70.

Pomies, D. and J. Bony. 2000. Comparison of hygienic quality of milk collected with a milking robot vs. with a conventional mikling parlor. Proceedings of the International Symposium Robotic Milking, p: 122-123 Lelystad, The Netherlands, 17-19 August 2000.

Radfor, T. 2003. Robot milking? Pull the udder one. http://www.guardian.co.uk/uk news/story/0,3604,911750,00. html

Rasmussen, M. D. and N. P. Madsen. 2000. Effects of Milkline Vacuum, Pulsator Airline Vacuum and Cluster Weight on Milk Yield, Teat Condition and Udder Health. Journal of Dairy Science, 83 (1):77-84.

Reinemann, D. J. and D. Jackson Smith 2000. Evaluation of Automatic Milking Systems for United States. in : Hoheveen, H. and Meijering, A. (editors) Robotic Milking, p: 122-123, Wageningen Pres., Wageningen, The Netherlands.

Reinemann, D. J. 2002. Application of Cleaning and Cooling Principles to Robotic Milking. DeLaval Inaugural Symposium, Kansas City Mo.

Reinemann, D.J., O. Lind and J. Rodenburg. 2002. A Global Perspective on Automatic Milking Systems Rules and Regulations. The First North American Conference on Robotic Milking, 20-22 March 2002, Toronto, Canada. 
Reinemann, D. J. and J. M. Helgren. 2004. ASAE/CSAE Annual International Meeting Paper Number:04-4191. Ontario, Canada, 1-4 August 2004.

Reinemann, D. J. 2005a. A review of Studies on the Ergonomics of Milking Research and Instruction Lab, March 2005.

http://www.uwex.edu/uwmril/pdf/MilkingParlors/05_Milki ngErgonomicsReview.pdf

Reinemann, D. J. 2005b. The History of Vacuum Regulation Technology. Annual Meeting of The National Mastitis Council, 2005.

Rodenburg, J. and D. F. Kelton 2001. Automatic Milking Systems in North America: Issue and challenges unique to Ontario; in: National Mastitis Council Annual Meeting Proceedings, p: 163-169. NMC.

Rodenburg, J. 2002. Strategies for Incorporating Robotic Milking into North American Herd Management. Ministry of Agriculture and Food 1.http://www.search.gov.on.ca:80002/compass?viewtemplate=simpleMadison, WI, USA.

Rossing, W., A. H. Ipema and P. F. Veltman. 1997. The Feasibility of Milking in a Feeding Box. IMAG Research Report 85-2, Wageningen, The Netherlands.

Schukken, Y H., H. Hogeveen and B. J. Smink. 1999. Mastitis Council Regional Meeting Proceedings (1999), pp 6469.

Stal, M. and T. Juliszewski. 2001. Analysiz of wrist angles and movements applied to machine milking. Farm Work Science Facing The challenges of the XXI Century. Proceedings XXIX CIOSTA GIGR V: Congress, p: 273276.Krakow, Poland, 25-27 June 2001.

Steevens, B. J. 1992. 'Economics of Parlor Size Versus Cow Numbers' in Proceedings from the National Milking Center Design Conference, p: 8-20. Harrisburg, Pennsylvania November 17-19, 1992, Northeast Regional Agricultural Enginerring Service, Ithaca, New York,

Täubert, H., W. Brade and H. Simianer. 2004. Genetic parameters of production traits in automatic and conventional milking systems. $55^{\text {th }}$ Meeting of the EAAP, Bled, Slovenia, September $5^{\text {th }}-9^{\text {th }} 2004$, Commission on Animal Genetics, Paper G4. 61.
Van der Vorst, Y. and H. Hogeveen. 2000. automatic milking systems and milk quality in The Netherlands, Proceedings of the International Symposium Robotic Milking, 73-82.Lelystad, The Netherlands, 17-19 August 2000.

Van der Vorst, Y. and K. De Koning. 2002.Automatic Milking Systems and Milk Quality in Three European Countries. The First North American Conferance on Robotic Milking-March 20-22,2002.V1-V13.

Van't Land, A., C. Van Lenteren, C. Bouwmans, E. Van Schooten, P. Hink and D. J. Gravesteyn. 2000. Effects of husbandry systems on the efficiency and optimization of robotic milking performance and management. International Symposium Robotic Milking 2000. http://www. automaticmilking.nl/

Vorst, Y., B. Kees, U. Wijbrand and P. Judith. 2003. Milk Quality on Farms with an Automatic Milking System. Research Institue for Animal Husbandry Lelystad, The Netherlands. http://www.automaticmilking.nl

Wagner, A. M. and R. W. Palmer. 2003. Feeding Behaviour, Milking Behavior and Milk Yields of Cows Milked in a Parlor Versus an Automatic Milking System. J. Dairy Sci. 86:1494-1502.

Wilson, A. 2003. Robotics heralds new era in dairy farming ,Vision System Design.

http://vsd.pennnet.com/Articles/Article Display.cfm?Sec tion=Articles\&Subsection=Display\&ARTICLE_ID=18202 9\&KEYWORD=iceroboticsü

Wirtz, N., K. Oechtering, E. Tholen and W. Trappmann 2001. Comparison of an automatic milking system with a conventional milking parlour. $52^{\text {nd }}$ Annual Meeting of the European Association for Animal Production. 26-29 August 2001.

\author{
İletişim Adresi: \\ Deniz ALIÇ \\ Ankara Üniversitesi Ziraat Fakültesi \\ Zootekni Bölümü \\ Tel: 03125961379 \\ E- posta: alicdeniz@hotmail.com
}

